Маја Р. Кујунџић

Универзитет у Источном Сарајеву 821.163.41.09-31 Андрић И.

Филозофски факултет Пале

Катедра за англистику

\title{
ПАСИВНЕ КОНСТРУКЦИЈЕ У ПРЕВОДУ АНДРИЋЕВОГ РОМАНА НА ДРИНИ ЋУПРИЈА НА ЕНГЛЕСКИ ЈЕЗИК
}

Циљ овог рада је да упореди употребу пасивне конструкције у енглеском преводу Андрићевог дјела „На Дрини ћуприја" са употребом исте у оригиналној верзији овог текста. Настојаће се утврдити да ли се пасивне конструкције у енглеском преводу нужно јављају у истом облику и у оригиналном тексту, другим ријечима, да ли је пасивна конструкција у енглеском преводу увијек пасивна и код Андрића. Ако то пак није увијек случај, покушаћемо утврдити када и зашто се енглеска и српска верзија ове конструкције налазе, односно, не налазе у односу преводне еквиваленције, те да ли се она дешава по одређеном обрасцу који је условљен семантичким, синтаксичким и стилским одликама ове конструкције у двама језицима.

Къучне ријечи: пасивна конструкција, оригинални текст, превод, типови пасива, српски језик, енглески језик, контрастивна анализа

\section{Увод}

Оно што се може издвојити као заједничко када је у питању виђење пасивне конструкције у енглеском језику,

* maja.kujundzic@ffuis.edu.ba 
сежући све од традиционалних па до савремених граматика енглеског језика, јесте чињеница да ја пасивна конструкција дефинисана у уској вези са њеним еквивалентом у активу, односно као облик изведен трансформацијом из њој одговарајуће активне конструкције путем процеса, у генеративној граматици, познатог као пасивизација. Томе свједоче дефиниције пасива из неких од најпризнатијих и најчешће употребљаваних савремених граматика енглеског језика, па тако Кверк и сарадници (1985), иако признају постојање атипичних пасивних конструкција које немају увијек своје директне еквиваленте у активу (енг. semi-passives и pseudo-passives; срп. полупасиви и nсеудоnасиви), ову конструкцију ипак дефинишу као облик настао из одговарајућег активног облика.

Наиме, они дефинишу глаголско стање као граматичку категорију која нам омогућава да радњу реченице изразимо на два различита начина, а да при томе не промијенимо њено чињенично значење. Та два различита начина вићења глаголске радње означена су као актив и пасив и један су са другим у уској трансформационој вези, на којој Кверк и сарадници базирају своју анализу пасива. Они тврде да веза између актива и пасива подразумијева два граматичка нивоа, а то су граматички ниво фразе и клаузе. На нивоу глаголске фразе пасив се разликује од актива по томе што умјесто простог глаголског облика садржи сложени, који се састоји од помоћног глагола to be праћеног партиципом прошлим, док на нивоу клаузе трансформација из актива у пасив доводи до промјене позиције два реченична елемента. Другим ријечима, субјекат активне реченице постаје објекат пасивне реченице, док објекат активне реценице постаје субјекат пасивне реченице у којој се појављује са препозицијом by. Таква препозицијска фраза са by најчешће ce назива by-agens (енг. agent by-phrase). Кверк и сарадници нам представљају своју класификацију пасива или 
пасивни градијент (енг. passive gradient) која обухвата сљедеће реченице (Кверк и др. 1985:167):

(1) This violin was made by my father.

(2) This cocnslusion is hardly justified by the results.

(3) Coal has been replaced by oil.

(4) This difficulty can be avoided in several ways.

(5) We are encouraged to go on with the project.

(6) Leonard was interested in linguistics.

(7) The building is already demolished. (69) The modern world is getting ['becoming'] more highly industrialized and mechanized.

Према Бајберу и сарадницима, већина пасивних конструкција гради се од помоћног глагола be којем слиједи партицип прошли. Осим помоћног глагола $b e$, они истичу да се и глагол get може појавити у пасиву у улози помоћног глагола. Што се тиче глагола који се могу појавити у пасиву, Бајбер и сарадници сматрају да је пасив могућ са већином прелазних глагола. Трансформацијом из актива у пасив, директни објекат активне реченице постаје субјекат пасивне, док субјекат постаје објекат пасивне реченице у којој се, у већини случајева, појављује у облику препозицијске фразе са by. Именичка фраза у оквиру ове препозицијске фразе најчешће се назива агенсом радње, иако она може имати и друге семантичке улоге.

Класификација пасива од стране Бајбера и сарадника чини се јединственом по томе што они дијеле пасиве на оне са статичним и динамичним глаголима, у складу с тим да ли описују „the state resulting from the action” или „an action rather than the resulting state” (Бајбер и др. 1999: 936), као у сљедећим примјерима: 
(3) Andy may be adopted.

(4) My car was broken into.

Дефиниција пасива од стране Хадлстона и Пулума (2002) базирана је на промјени синтаксичких улога одређених реченичних елемената у пасиву у поређењу са његовим еквивалентом у активу. На примјер, субјекат у активу је поистовјећен са улогом агенса радње, док субјекат у пасиву најчешће трпи одређену радњу. У вези са овим више је него очигледно да су сами називи за актив и пасив базирани на семантичким улогама њихових субјеката. Према Хадлстону и Пулуму, активне и пасивне реченице се разликују према својим синтаксичким особинама на четири различита начина: 1. субјекат активне реченице појављује се у пасивној реченици као комплемент препозиције $b y$; 2 . објекат активне реченице појављује се као субјекат у пасивној реченици; 3. глагол активне реченице се у пасивној реченици појављује у облику прошлог партиципа; 4. пасивна реченица садржи помоћни глагол to be као екстра или додатни елемент. (Хадлстон и Пулум 2002: 1427):

(5) Oswald assasinated Kennedy.

(6) Kennedy was assasinated by Oswald.

Аутори даље наводе да се глаголски елемент у пасивној коснтрукцији гради уз помоћ глагола to be и прошлог партиципа одговарајућег глагола, при чему истиче да то увијек мора бити транзитивни глагол, јер само они имају ту способност да узму облик пасива.

(7) Актив: Charles Dickens wrote many novels.

(8) Пасив: Many novels were written by Charles Dickens.

Као разлика између ове двије реченице наводи се позиција субјекта и објекта, који заузимају двије крајње 
и супротне позиције у поређеним реченицама. У пасивној реченици, ономе што је представљало субјекат у активној реченици претходи приједлог $b y$, а глаглоском облику wrote који се појављује у активу, у пасиву одговара сложенија глаголска конструкција were written.

У Лонгмановој граматици енглеског језика, Александер објашњава пасивну конструкцију контрастирајући је са њом одговарајућим обликом у активу при чему као основну разлику између ове двије конструкције наводи чињеницу да субјекат у активној реченици јесте особа или предмет који је вршилац радње као у реченици (2003: 182).

(9) John burnt the dinner last night.

За разлику од актива, у пасивној реченици онај или оно што је било вршилац радње, постаје њен објекат, као у сљедећој реченици (2003:182):

(10) The dinner was burnt.

Аутор даље наводи да се глаголски елмент у пасивној конструкцији гради уз помоћ глагола to be и прошлог партиципа одговарајућег глагола, при чему истиче да то увијек мора бити транзитивни глагол, јер само они имају ту способност да узму облик пасива.

Дакле, све наведене дефиниције виде пасивну конструкцију као конструкцију насталу конверзијом из одговарајуће активне конструкције, а која се састоји из одговарајућег облика глагола to be (ријеђе to get) и партиципа прошлог прелазног глагола.

И случају спрског језика, пасивна конструкција је такође одувијек изазивала велико интересовање лингвиста, па на њене описе наилазимо како у раним традиционалним, тако и у савременим граматикама српског језика. 
У Стевановићевој „Граматици српскохрватског језика"(1951), пасивна конструкција је описана у поглављу чији је примарни назив „трпно стање”. Према аутору ова конструкција се употребљава у случајевима када је умјесто вршиоца радње објекат радње потребно представити као средиште излагања тј. као граматички субјекат. Облици трпног стања се углавном граде попут сложених облика радног стања, с том разликом што се умјесто радног употребљава трпни придјев - „ухваћен сам, ухваћен си, ухваћен је, итд.” (1951: 224). Истина је да се овакве глаголске радње могу исказивати и помоћу облика радног стања са повратном речцом се, с тим да се ови облици најчешће користе за означавање трпног стања радње која се неком приписује за вријеме у коме се говори или која се врши по неком уобичајеном реду (најчешће у облику презента) - „То је писац који се данас најчешће чита; Жита која се сеју с јесени, сазревају у почетку лета" (1951: 224).

За детаљније разумјевање пасива у српском језику од велике користи је и Стевановићево (1969) поглавље о глаголском роду и сродним питањима, која неминовно укључују и бављење пасивном конструкцијом. Наиме, у већини случајева пасивна конструкција је описана као настала из одговарајуће активне конструкције тако што објекат активне реченице постаје субјекат пасивне, а постојање објекта у активној реченици подразумијева и постојање прелазног глагола. У вези са овим сасвим је јасно како бављење глаголским родом доприноси разумијевању пасива. Стевановић се на веома детаљан и посвећен начин бави овим питањем, разоткривајући многе заблуде и недостатке када је у питању начин на који је пасивна конструкција бивала схваћена у његовом времену, у исто вријеме бацајући свјетлост на могуће неодостатке дефиниција пасива на које наилазимо у савременим граматикама српског језика. 
У Белићевој „Историји српскохрватског језика” (1962) пасивна конструкција је такође описана под називом „трпно стање”, које се исказује глаголским придјевом трпним на $u$ или $m$ и од несвршених или свршених глагола, при чему је носилац времена помоћни глагол јесам - бити, са пуним и енклитичким облицима јесам или са глаголом бивати у итеративном значењу.

Аутори у „Граматици хрватскосрпског језика (Брабец, Храсте, Живковић: 1970) говоре о пасиву у поглављу које се бави глаголским стањем. Разлика између актива и пасива прави се на основу тога да ли субјекат врши радњу или се радња врши на њему, па се у првом случају такве реченице називају активним или радним, а у другом трпним или пасивним. Презент трпног стања (пасива) гради се од глагола бивати за несвршено значење (трајно или учестало) и од трпног придјева глагола који се конјугира. Остала времена и облици творе се од облика глагола бити и трпног придјева глагола (за несвршену и свршену радњу). Попут Стевановића, а за разлику од Белића, овај приказ пасива такође наводи могућност исказивања пасивне конструкције повратним глаголом - „Ливаде се косе више пута у години. Љети се много пије воде." (1971: 127). Занимљиво би било обратити пажњу на напомену која стоји на дну поглавља, а која каже да се у нашем језику пасив ријетко употребљава у случајевима када је у реченици наведен агенс.

Будући да обим овог рада не дозвољава детаљније бављење природом пасивне конструкције, овдје ћемо се фокусирати на сажете и једноставније дефиниције пасива, које ће нам послужити као водиља приликом препознавања основних и очигледних типова пасивне конструкције. Па тако у једној од, међу младима, најкориштенијих граматика спрског језика (Станојчић, Поповић: 1995), пасивна конструкција је описана као специјална конструкција (с партиципским пасивом), 
која се јавља само у реченицама са прелазним глаголима (и то не свим). У оваквим реченицама пацијенс је исказан субјектом , глагол је у пасивном облику, а агенс у случају да је изражен, што се дешава јако ријетко, изражен је уз помоћ агентивне одредбе која се типично састоји од „од (-стране)” и именичке јединице у генитиву. Поред оваквих партиципских пасивних конструкција, наводе се и конструкције са рефлексивним пасивом, за исказивање ситуације са уопштеним или колективним агенсом. Дакле, овакве конструкције, како сам назив каже, имају глагол у рефлексивном облику, субјектом је исказан пацијенс, а агенс се типично не изриче тј. реченица је деагентизована.

У Симићевој „Граматици српског језика” (2001), пасив је дефинисан као граматички облик којим се обиљежава да „субјекат реченице није вршилац радње, већ је радњом обухваћен као објекат” (2001: 127 ). Оваква конструкција јавља се у двије форме, у сложеној глаголској форми која се састоји од помоћног глагола бити и трпног глаголског придјева, и у форми повратних глаголских облика.

„Нормативна граматика спрског језика” (Пипер, Клајн: 2015) пасив дефинише као конструкцију која се у српском језику употребљава првенствено за радње чији се вршилац не зна или се сматра да не мора бити поменут. И ова као и претходне двије граматике наводе два облика у којима се ова конструкција јавља. Партиципски пасив, који се састоји од сложених облика помоћног глагола бити и одговарајућих облика трпног придјева, те замјенички пасив који је исказан „повратним, предикатски употријебљеним обликом глагола који иначе није повратан, који је несвршен и прелазан” (2015:188).

У свим горенаведеним дефиницијама пасива, као и у енглеском језику, пасивна конструкција описана је у уској вези са њој одговарајућом активном конструкцијом 
(са прелазним глаголом), из које се добија процесом конверзије приликом које објекат активне реченице постаје субјекат пасивне, при чему је субјекат активне реченице у пасивној најчешће изостављен или, у ријетким случајевима када то није бива изражен уз помоћ агентивне одредбе. У описима пасива најчешће се помињу два типа пасива, партиципски који се састоји од помоћног глагола бити и трпног партиципа, те рефлексивни који се заснива на употреби енклитичког облика се (поријеклом од замјенице себе) у конструкцији са личним глаголским облицима.

Дефиниција којом смо се користили у овом раду, на суштински исти начин дефинише пасивну конструкцију, међутим, учинила нам се најсажетијом и најсвеобухватнијом, јер поред тога што на веома сажет и прецизан начин дефинише партиципске и рефлексивне пасиве, које назива замјеничким пасивима, ова дефиниција укључује и још један ријетко помињани тип пасива, а то је адвербијални пасив. Код ове врсте пасива, предикатом је означен процес због којег пасив привремено није на свом уобичајеном мјесту, па је у том случају приликом трансформације активне реченице у пасивну, предикатско значење изражено глаголском именицом у именском дијелу предиката и помоћним глаголом, а агенс је изражен именским изразом са приједлогом код (Танасић у „Синтакса савременог српског језика”, 2005: 669), као у примјеру који слиједи:

(11) Књига је на читању код Пере Перића.

\section{Анализа}

На самом почетку неопходно је било одредити радну дефиницију пасива на којој ће ово истраживање почивати, те на основу које ће релевантни примјери ове кон- 
струкције бити идентификовани у тексту и накнадно подвргнути детаљнијој лингвистичкој анализи у складу са основним циљем овог рада. У складу са тим, одлучено је да у фокусу овог рада буду искључиво финитни пасиви, што је с једне стране условио сам обим рада, а са друге стране чињеница да су нефинитни пасиви недовољно обрађени, те нејасно дефинисани у литератури о пасиву. Наиме, њихово помињање је готово у потпуности изостављено у енглеским граматикама или сведено само на веома штуро помињање у граматичким поглављима која се не баве искључиво пасивном конструкцијом већ другим нефинитним глаголским облицима попут герунда и инфинитива. Када су у питању финитни пасиви, као главна водиља послужила је дефиниција пасива од стране Кверка и сарадника (1985) који ову конструкцију дефинишу као комбинацију помоћног глагола be (или get) и прошлог партиципа активног глагола. Проблем код овакве дефиниције пасива, јесте тај што обухвата и неке „нетипичне” примјере пасива који немају своје директне еквиваленте у активу, те је поприлично нејасно да и њихови партиципи имају статус глагола или придјева, или су морфолошки изоловани путем процеса прављења сложеница, те су из тог разлога названи полупасивима или псеудопасивима. Како је статус оваквих пасивних конструкција поприлично нејасан и дискутабилан, у овом раду смо се одлучили концентрисати на категорију централних или правих пасива, који за разлику од претходно поменутих имају своје директне еквиваленте у активу тј. чији партиципи су у потпуности глаголске природе.

Када су у питању пасивне конструкције у српском језику, дефиниција на којима почива њихово виђење и класификација, преузета је из „Синтаксе савременог српског језика” (2005). Ова дефиниција, као и енглеска, пасив описује као облик изведен из њој одговарајуће 
активне конструкције. Наиме, различити облици ове дијатезе организовани су око категорије глаголског рода који је бинарна категорија у оквиру које су облици са пасивним значењем формалном маркираношћу супротстављени облицима који могу да значе како пасивност тако и агентивност, у зависности од лексичког значења предиката и аргумента. Постоје два основна начина да се активна реченична конструкција трансформише у пасивну: замјенички и партиципски.

Замјенички пасив заснива се на употреби енклитичког облика се (поријеклом од замјенице себе) у конструкцији са личним глаголским облицима (Кућа се зида; Пруга се гради.).

Партиципски пасив садржи у својој структури пасивни партицип, тј. трпни придјев у конструкцији са неким од облика глагола бити (Ручак је скуван; Биће потписан уговор).

Као трећи тип пасива спомиње се и адвербијални пасив који се јавља у случају када је предикатом означен процес због којег пацијенс привремено није на свом уобичајеном мјесту, па тада трансформација активне реченице у пасивну тражи да предикатско значење буде изражено глаголском именицом у именском дијелу предиката и помоћним глаголом. (Књига је на читању код Пере Перића; Кола су на поправци код бата Колета).

Сто педесет примјера пасивне конструкције прикупљено је консекутивним слиједом, од самог почетка књиге па надаље, а затим су упоређени са изворним језичким формама из којих су потекли у оригиналном тексту. Квантитативни резултати анализе, који искључују улазак у сферу глаголске семантике, те других релевантних фактора који су утицали на употребу пасивне конструкције у енглеском преводу, су показали да је највећи број централних или правих пасива у енглеском преводу резултирао из партиципских пасива у изворном 
тексту (57 примјера), њима слиједе активне конструкције (55) које се јављају у занемарљиво мањем броју, док се на посљедњем мјесту по бројности јављају замјенички или рефлексивни пасиви (37). Било би занимљиво примјетити да ниједан од издвојених примјера пасива пронађених у енглеском преводу није проистекао из типа адвербијалног пасива у оригиналном тексту што би могло бити објашњено тиме што то није књижевно-умјетничка форма, него више разговорна, односно производ стварања говорних образаца.

Чињеница да је највећи број пасивних конструкција у енглеском тексту Андрићевог дјела настао као преводни еквивалент партиципских пасива у оригиналној српској верзији текста може бити објашњен директном формалном и семантичком подударношћу ових двију пасивних категорија у енглеском и српском језику. Када је у питању формална подударност овај тип пасива у српском језику се дословно може пресликати на тип централног или правог пасива у енглеском језику - оба се састоје од граматичком лицу одговарајућег облика помоћног глагола бити (енг. to be; срп. битu) те пасивног партиципа глагола из активне реченице, који је, како у енглеском централном пасиву, тако и у српском партиципском пасиву настао искључиво од прелазних глагола. Наиме, у оба случаја се ради о безличном глаголском облику који означава да се на некоме или нечему врши, се (из) вршила или ће се вршити нека радња. Другим ријечима, описује се да неко или нешто трпи вршење радње, што је у српском језику врло досљедно и сликовито описано термином који се користи упоредо са термином пасивни партицип, а то је глаголски придјев трпни, те стога није случајно да се пасив у српском језику још назива и трпно стање. Ово илуструју сљедећи примјери:

(12) The man was impaled on the stake as a lamb on the spit, only that the tip did not come through the mouth but in 
the back and had not seriously damaged the intestines, the heart or the lungs. (str. 66)

(13) Човек је био набијен на колаи, као јање на ражањ, само што му врх није излазио кроз уста него на леђа и што није јаче озледио ни утробу ни срце ни плућа. (стр. 52)

Сама чињеница да се у оба случаја ради о партиципима прелазних глагола који по својој дефиницији захтијевају прелазност радње тј. морају имати допуну у виду објекта, одређује њихову семантику, па се у случају оба језика ради о глаголима који својим значењем обухватају постојање објекта на којег је усмјерена радња смјештена у датом глаголском облику.

Преводна подударност ова два типа пасива даље може бити објашњена тиме што се у оба језика у огромној већини случајева јављају без израженог агенса. У партиципским пасивима у српском језику именовање агенса „није искључено иако није ни често.” (Синтакса савременог српског језика: 625). Ово се слаже са налазима неких од најбољих познавалаца енглеског пасива, Свартвика (1969) као и Кверка и сарадника (1985), који у својим веома детаљим истраживањима ове конструкције закључују да централни (прави) пасиви без агенса представљају најфреквентнији тип пасива. Ово бива потврђено и у нашем случају гдје у укупном броју пасива овог типа у енглеском преводу ${ }^{1}$ (57) и у оригналном српском тексту ${ }^{2}$ налазимо свега шест примјера пасивне конструкције са израженим агенсом.

Осим наведних подударности, највећа бројност партиципских пасива у односу на друге типове пасива,

1 Андрић 1963: И. Андрић, На Дрини Ћуnрија, Загреб: Младост

2 Андрић 2017: И. Андрић, The Bridge on the Drina, прев. Ловит Ф. Едвардс/Lovett F. Edwards, Подгорица: Нова књига 
тачније речено у односу на замјеничке (рефлексивне пасиве), може бити објашњена и тиме што је овај тип пасива сликовитији и дескриптивнији у односу на замјенички пасив јер садржи трпни придјев, па је самим тим и наративнији, што управо одговара оваквој књижевној форми.

Када су у питању замјенички пасиви, њихов број је знатно мањи у односу на партиципске у укупном броју пасивних конструкција из оригиналног текста које су у енглеском тексту такође преведене пасивном конструкцијом. Овај тип пасива је, насупрот партиципском, по својим формалним и семантичким карактеристикама много удаљенији од енглеских централних или правих пасива. Наиме, у енглеском језику не налазимо облике пасива који се у својој форми састоје од енклитичког облика у комбинацији са личним глаголским облицима, при чему морфема се није сигнал ни реципрочности ни транзитивности него пасивности. Претпостављамо да је управо оваква формална неподударност између енглеског централног и српског замјеничког пасива у великој мјери утицала на то да овај тип пасива, у односу на партиципски, знатно рјеђе у енглеском преводу нађе свој директни еквивалент у енглеском централном пасиву. С обзиром на то да је ово истраживање за полазишну тачку имало енглески превод, а не српски изворни текст, у неком од наредних истраживања било би занимљиво видјети које се конструкције поред енглеског централног пасива јављају као преводни еквиваленти замјеничког пасива у енглеском језику.

У литератури о пасиву такође се наводи да се замјенички пасиви користе често за исказивање ситуације са уопштеним или колективним агенсом који се односи на особе. Ово потврђују и наши примјери замјеничког пасива код којих се у огромној већини случајева управо ради о уопштеном или колективном агенсу, као у примјерима: 
(14) In all tales about personal, family or public events the words 'on the bridge' could always be heard. (str.22)

(15) У свима причањима о личним, породичним и заједничким доживљајима, могу се увек чути речи »на ћуприји«. (стр. 12)

(16) Then, all day long, there could be seen travellers coming from Bosnia who stood on the farther bank in desperation, frozen and drenched, vainly watching the ferry and the ferryman and from time to time yelling long drawn summonses. (str. 33)

(17) Тада преко целог дана могу да се виде на другој обали путници, који долазе од Босне и који као очајници стоје на каменитој обали, одакле, озебли и покисли, узалуд изгледају скелу и скелеџију и с времена на време пуштају изнад мутне, бесне реке отегнута дозивања. (стр. 21)

У вези са овим може се претпоставити да би овај тип пасива био у много фреквентнијој употреби у текстовима научне природе, чији циљ управо и јесте доношење општих закључака, за разлику од романескне форме која се најчешће бави конкретним догађајима, као и конкретним актерима везаним за исте, што додатно објашњава мањи број замјеничких у односу на партиципске у укупном броју прикупљених пасива у изворном тексту. Чињеница да је овај тип пасива, као и партиципски у преводу резултирао истим типом енглеског пасива, већ је објашњен тиме да у енглеском језику не постоји одређени тип пасива који би се по својим формалним и семантичким карактеристикама могао искључиво везати за замјенички пасив, па се и овај тип пасива, као и партиципски, преводи централним пасивом, који се у 
енглеском језику користи за исказивање ситуације како са конкретним тако и са уопштеним или колективним агенсом.

Било је очекивано да ће пасивне конструкције пронађене у енглеском преводу, природном инерцијом наћи своје преводно упориште у пасивним конструкцијама у изворном тексту, међутим, испоставило се да је број активних конструкција које су у енглеском преводу резултирале пасивним конструкцијама готово исти као и број партиципских пасива. Активне конструкције које су у енглеском преводу резултирале пасивом, бројније су, дакле, и од замјеничких пасива, који иако, из наведених разлога јесу, у поређењу са партиципским пасивима удаљенији од енглеских правих пасива, ипак у својој суштини представљају изворне примјере пасива. У вези са овим покушали смо изнаћи разлоге који су довели до тога да активне реченице у изворном тексту на српском језику резултирају пасивним реченицама у енглеском преводу.

Како форма ових двају конструкција у енглеском и српском језику ни у ком случају не може бити доведена у везу, као што је био случај са партиципским пасивима, а још мање са замјеничким, који иако формално не наликују енглеском правом пасиву, опет сасвим јасно указују на то да њихов субјекат трпи радњу која се на њега усмјерава путем рефлексивног енклитичког облика се, у овом случају нам је преостало да се усмјеримо на семантику активног глагола, те да на тај начин покушамо објаснити зашто и како је исти у енглеском преводу резултирао пасивном конструкцијом.

Том приликом уочено је да већина активних српских глагола који се у енглеском преводу налазе у пасивном облику, у својој семантици носе значење наметања, присиле или морања којима је објекат изложен. Будући да пасивна конструкција објекат активне радње издваја 
из контекста стављајући га на прво мјесто у пасивној конструкцији, те на тај начин појачава и истиче стање трпљења у којем се дати објекат налази, не изненађује чињеница да аутор приликом превођења оваквих глагола на енглески језик посеже управо за пасивном конструкцијом, као у сљедећим примјерима у којима су дјеца одвођена без њихове воље и пристанка, а човјек мучен, сувишно је рећи, без свог пристанка:

(18) Then they would fly in all directions and hide in the forests along the roadsides, only to gather again a little later behind the convoy and strive with tear-filled eyes to see once again over the panniers the heads of the children who were being taken from them. (str.34)

(19) Оне би се тада разбежале и посакривале у шуму поред пута, али би се мало после опет сакупљале иза поворке и напрезале да сузним очима још једном угледају изнад сепетке главу детета које им одводе. (стр. 23)

(20) In the stable and around it reigned a sort of solemn emotion and a special silence as there is in places where one extracts the truth, a living man is tortured or where fateful things occur. (str. 61)

(21) У појати и око ње владало је неко свечано узбуђење и нарочита тишина као што увек бива на местима на којима истерују правду, муче жива човека или се дешавају судбоносне ствари. (стр. 47)

Занимљиво је примјетити да преводилац у случајевима када наилази на српски глагол који има рефлексивну ријеч уза се, али показују да субјекат не врши радњу својом вољом, у енглеском језику преводи пасивом. Дакле, преводилац на енглески језик српске неправе 
повратне глаголе управо зато што субјекат уз њих не врши означену радњу свјесно својом вољом доживљава као пасив, па их тако и преводи као пасив. Ово се може довести у везу са чињеницом да је у неким индоевропским језицима позната категорија медиопасива ${ }^{3}$. Симеон (1969:33) за ове глаголе, поред термина медиопасиви, користи и назив пасивно-медијални и дефинише их као „оне који су у медију добили рефлексивно или транзитивно значење”. То је еквивалентно статусу неправих повратних глагола у српском који у енглеском преводу добијају пасивну дијатезу:

У првом примјеру глагол покорити подразумијева дијалошки контекст, укључује више гласова, глас онога који намеће и глас онагога који трпи, као у:

(22) When the Vezir, Mehmed Pasha, had first thought building the bridge on the Drina and sent his men here, everyone submitted and was summoned to forced labour. (str.25)

(23) И кад је везир Мехмедпаша наумио да зида мост на Дрини и послао људе, све се покорило и одазвало на кулук, само је устао тај Радисав, подбунио народ и поручио везиру да се окане тога посла, јер неће, шале, подићи ћуприје на Дрини.

Сличан је и сљедећи случај у којем се опет ради о наметнутој радњи, нечему што је неко под отежаним околностима, те под притиском морао да прихвати.

3 медиопасивус - глаголска категорија, средња између медија и пасива, нпр. vertor 1. (окређем се), хр.; глаголски лик у неким индоевропским језицима, у којем глаголски облици имају медијално и пасивно значење речи; сустав глаголских облика који имају медијално значење и наставке за пасив, типа латинског депонентног lavor = перем 
(24) They tell the tale that Starina Novak, when he felt his strength failing and was compelled to give up his role as highwayman in the Romania Mountains, thus taught the young man Grujic who was to succeed him. (str. 29)

(25) Прича се да је Старина Новак, кад је изнемогао и морао да се повуче и напусти хајдуковате по Романији, овако учио Дијете Грујицу, кад је требало да га замени. (стр.18)

У наредном примјеру преводилац је највјеровантије сматрао да дјеца нису била сама у стању да се испењу на високе камене блокове па су на исте постављени уз помоћ одраслих, те у складу са тим и користи пасивну констуркцију са глаголом hoist који значи - noдuћu, уздићu.

(26) Children were hoisted on to high blocks of building stone which were lying about. (str.62)

(27) Деца су се испела на високе блокове необрађеног камена који су ту лежали. Стр. 48

Или пак случај у којем вршилац радње опет није учинио нешто својевољно него му је то наређено. Дакле, војницима је било наређено да се распореде у два реда.

(28) Ten guards were drawn up in two ranks, five on either side. (str.63)

(29) Десетак сејмена се сврста у два реда, по пет са сваке стране. (стр. 49)

Такође је примијећено да у случају активних глаголских фраза у којима је субјекат апстрактна појава која објекат радње ставља или га излаже одређеном стању трпљена без његове воље, преводилац на енглески језик 
их преводи пасивом. Па тако и у примјеру који слиједи имамо перифразу глагола заспати или фразеологизиран идиоматски израз. Наиме, глагол стања заспати перифразом се претвара у идиоматски израз у коме се ствара привид синтаксичко-семантички активне конструкције у којој је сан вршилац радње. Будући да је сан апстрактна појава стања коме је субјекат изложен цијела конструкција дјелује на семантичком плану као пасивна.

(30) But the children who, torn between belief and unbelief, remained on vigil by the windows overlooking Radisav's tomb have never managed to see this heavenly fire, for they were all overcome by sleep before midnight came. (str.26)

(31) Али дечаци који су, и верујући и не верујући, остајали да бдију поред прозора са изгледом на Радисављев гроб, нису никад успевали да виде небеску ватру, јер би их још пре поноћи савладао сан. (стр. 15)

У примјерима који слиједе као и упретходном, потреба u равнодушност представљају субјекте апстрактне природе који објекте радње без њихове воље стављају или излажу одређеном стању, па преводилац, како би нагласио њихову позицију трпљења радње тј. наметнуто стање, одлучује у енглеском преводу употријебити пасивну конструкцију која управо ставља акценат на поменуту перспективу. Осим тога, конструкција „мучила га је потреба” има свој конверзив у субјекатско-предикатско-објекатском активном конверзиву „осјећао је потребу”, тако да је и у српском „мучила га је потреба” - семантички и из тих разлога пасивно, па се може рећи да је то управо пасивна перифраза активне конструкције. Исти случај је и са примјером „хватала га је равнодушност” који је трансформисан из „осјећао је равнодушност”, па стога можемо рећи да су то перифрастичне пасивне форме којима се изражавају глаголи стања или осјећања. 
(32) All his muscles twitched, he could no longer keep still, but was constantly tormented by the irresistible urge to prove to himself and show others that he was still healthy, whole and capable of movement. (str.77)

(33) Сви мишићи су на њему поигравали, место га није држало, стално га је мучила неодољива потреба да се и сам увери и другима да покаже како је он здрав, читав и покретан. (стр. 62)

(34) The man from Plevlje was seized with a mortal apathy. (str.53)

(35) Плевлька је хватала самртна равнодушност. (стр.40)

Такође је примјећено и да преводилац на енглески језик посеже за пасивном конструкцијом у случајевима када преводи безличне глаголске конструкције или уопштено личне конструкције које се односе на људе уопште. У том случају најчешће се ради о глаголима који подразумијевају обавезу која се односи на људе уопште („треба да се зна”), или о глаголима тврђења и порицања који указују на неки општеприхваћени став или очигледну чињеницу коју стога већина мора прихватити као такву („разуме се”; „не може се порицати”). Овакви безлични облици у нашем језику, у енглеском се исказују у трећем лицу једнине средњег рода:

(36) Then, it was understood, there was no loitering on the open terraces of the kapia. (str. 28)

(37) Тада, разуме се, нема задржавања на отвореним терасама на капији. (стр.17) 
(38) In any case, it cannot be denied that the people of Vishegrad have from olden times been considered, in comparison with the people of other towns, as easy-going men, prone to pleasure and free with their money. (str. 29)

(39) Свакако, не може се порицати да су Вишеграђани од давнина важили, у поређењу са становницима других места, као људи лакомислени, склони уживањима, и брзи на трошак. (стр.18)

У сличној употреби често се наилази на глаголе опажања као сто су видјети, чути и сл. који не подразумјевају конкретног вршиоца радње те истичу да дате појаве могу бити перципиране од стране било кога ко се налази у њиховом опсегу. Разумљиво је да преводилац у овим случајевима гдје конкретни актери радње нису битни нити истакнути посеже за пасивом који управо пружа ту могућност да се изостави агенс а фокус умјесто на вршиоца радње, усмјери на саму радњу. У складу са наведеним ове конструкције бисмо могли окарактерисати као пасивно-безличне конструкције (Симеон, 1996: 33). Ове конструкције није уобичајено користити у енглеском језику, осим уз глаголе опажања ( нпр. say, think, know), што је потврдило и наше истраживање.

(40) Deep among the hills the clouds lay in long dull purple bands and between them could be seen the clear sky almost green in colour. (str.61)

(41) Дубоко међу брдима видели су се облащи, растегнути у дугим, загаситољубичастим појасевима, а између њих светло и бистро небо, готово зелене боје. (стр.47)

Глаголи градити, зидати, подићи у активном облику, када се односе на грађење моста, преводилац често одлучује превести у пасивном облику. Наиме, мост, по којем је 
и сам роман добио назив, јесте централно мјесто његове радње, а његов значај и симболика превазилази, како животни вијек тако и значај, ако не иницијатора његове градње онда посве сигурно његових физичких градитеља, па они јако често, осим ако нису умијешани директно у битне догађаје који су везани за његову градњу, не бивају поменути, што нам управо пасивна конструкција и омогућава. Насупрот овоме, за разлику од условно речено „небитних” физичких извођача радова на мосту, у случајевима када се ради о самом иницијатору овог пројекта, великом везиру Мехмед Паши Соколовићу, те познатом зидару Раду Неимару као главном управљачу свих радова, агенси нису изостављени, упркос чињеници да се дуги пасиви генерално веома ријетко јављају, што додатно поткријепљује њихову битност како за радњу романа тако и за шири историјски контекст. Одлука преводиоца да у овим случајевима посегне за дугим пасивом може такође бити објашњена такозваним „информацијским током” или „информационим принципом” који се односи на начин на који су елементи у реченици распоређени на основу тога да ли преносе стару или нову информацију. Будући да се стара или позната информација односи на контекст који претходи, она се обично ставља на почетак реченице јер на тај начин обезбјеђује везу са оним што је претходно речено, док се нова информација јавља нешто касније у слиједу како би се могла даље разрадити у истој реченици или пак у дискурсу који слиједи, што је случај у наведеним примјерима. Наиме, употреба пасивне конструкције је омогућила да се мост који је познат из претходног контекста стави у иницијалну позицију, како би се помињање агенса одгодило за касније и дало нам прилику да детаљније опишемо њихов идентитет. И прва и друга поменута употреба пасива илустроване су примјерима који слиједе: 
(42) So great a mass of scaffolding arose on both banks of the Drina that for long the people thought that the bridge would be built of wood. (str. 40)

(43) Толика се јапија слегла на обе стране Дрине да је свет дуго времена мислио да ће мост градити од дрвета. (стр. 28)

(44) They knew that the bridge had been built by the Grand Vezir, Mehmed Pasha, who had been born in the nearby village of Sokolovici, just on the far side of one of those mountains which encircled the bridge and the town. (str. 22)

(45) Они су знали да је мост подигао велики везир Мехмедпаша, чије је родно село Соколовићи ту, иза једне од ових планина које окружују мост и касабу. (стр. 12)

(46) It was built by Rade the Mason, who must have lived for hundreds of years to have been able to build all that was lovely and lasting in the Serbian lands, that legendary and in fact nameless master whom all people desire and dream of, since they do not want to have to remember or be indebted to too many, even in memory. (str. 22)

(47) Зидао га је Раде Неимар, који је морао живети стотинама година да би саградио све што је лепо и трајно по српским земљама, легендарни и стварно безимени мајстор каквог свака маса замишља и жели, јер не воли да много памти ни многима да дугује, чак ни у сећању. (стр. 12)

\section{Закључак}

Било је очекивано да ће српске пасивне конструкције, попут партиципских, које су по својим формалним и семантичким карактеристикама готово идентичне са 
енглеским правим или централним пасивима, у истим и наћи своје преводне еквиваленте у енглеској верзији оригиналног српског текста, што је наше истраживање и потврдило. Замјенички пасиви, за разлику од партиципских, по својим формалним и семантичким карактеристикама много су удаљенији од енглеских централних или правих пасива.

Претпоставили смо да ће управо оваква неподударност измјеђу енглеског централног и српског замјеничког пасива у великој мјери утицати на то да овај тип пасива, у односу на партиципски, знатно рјеђе у енглеском преводу нађе свој директни еквивалент у енглеском централном пасиву, што је овај рад опет у великој мјери потврдио. Као што је већ речено, с обзиром на то да је ово истраживање за полазишну тачку имало енглески превод, а не српски изворни текст, у неком од наредних истраживања било би занимљиво видјети које се конструкције поред енглеског централног пасива јављају као преводни еквиваленти замјеничког пасива у енглеском језику.

За разлику од оваквих, највећим дијелом, очекиваних резултата, оно што нас је поприлично изненадило јесте чињеница да је велики број активних глаголских фраза из оригиналног српског текста, у енглеском преводу резултирало пасивним конструкцијама. Анализом оваквих примјера, који су по бројности чак у истој равни са партиципским пасивима, дошли смо да закључка да је, у оваквим случајевима преводиочев избор пасивне конструкције као преводног еквивалента активној конструкцији у српском оригиналном тексту у првом реду био условљен и мотивисан глаголском семантиком. У вези са тим, сасвим је логично да преводилац посеже за пасивном конструкцијом у случајевима када семантика активног глагола на српском језику подразумијева радњу у којој је објекат изложен трпљењу радње без сопствене воље и пристанка, те пасивна конструкција као „трпно 
стање”, преводиоцу управо даје прилику да истакне овакав положај објекта, стављајући га на прво мјесто у реченици, а у исто вријеме одгађајући помињање субјекта за крај реченице или изостављајући га у потпуности. Слично се дешава и у случајевима када преводилац наилази на српски глагол који има рефлескивну ријеч уза се али показују да субјекат не врши радњу својом вољом, па их у енглеском језику преводи пасивом. Дакле, преводилац на енглески језик српске неправе повратне глаголе, управо зато што субјекат уз њих не врши означену радњу свјесно својом вољом доживљава као пасив, па их тако и преводи пасивном конструкцијом у случајевима када преводи безличне глаголске конструкције или уопштено личне конструкције које се односе на људе уопште. Разумљиво је да преводилац у овим случајевима гдје конкретни актери радње нису битни нити истакнути посеже за пасивом који управо пружа ту могућност да се изостави агенс а фокус умјесто на вршиоца радње, усмјери на саму радњу. Насупрот оваквим случајевима у којима вршиоци радње нису битни, у случајевима када се ради о веома битним агенсима, они сасвим логично нису изостављени, а одлука преводиоца да у овим случајевима посегне за дугим пасивом умјесто за активном конструкцијом може бити објашњена такозваним „информацијским током” или „информационим принципом” који се односи на начин на који су елементи у реченици распоређени на основу тога да ли преносе стару или нову информацију. Будући да се стара или позната информација односи на контекст који претходи, она се обично ставља на почетак реченице јер на тај начин обезбјеђује везу са оним што је претходно речено, док се нова информација јавља нешто касније у слиједу како би се могла даље разрадити у истој реченици или пак у дискурсу који слиједи, што је случај у наведеним примјерима. 
Све ово указује на савршену способност језика да недостатности у својим одређеним сегментима, надокнади и надомјести већом елаборираношћу у неким другим. Тако у случајевима гдје је један језик мање синтаксички разуђен, ова недостатност се надокнађује семантичком компонентом, и обрнуто, што је, сасвим очигледно, показао и овај рад.

\section{Литература}

Андрић 1963: И. Андрић, На Дрини Ћуприја, Загреб: Младост. Андрић 2017: И. Андрић, The Bridge on the Drina, прев. Ловит Ф. Едврадз/Lovett F. Edwards, Подгорица: Нова књига.

Александер 1988: L. G. Alexander, Longman English Grammar, London/New York: Longman.

Бајбер и др. 1999: Biber et al., Longman Grammar of Written and Spoken English, London: Longman.

Белић 1962: А. Белић, Историја Српскохрватског језика, Београд: Научна књига.

Брабец и др.1970: И. Брабец и др., Граматика Хрватскосрпског језика, Загреб: Школска књига.

Гринбаум, Нелсон 2013: S. Greenbaum, G. Nelson, An Introduction to English Grammar, Oxon etc.: Routledge

Кверк и др. 1985: R. Quirk et al., A Comprehensive Grammar of the English Language, London: Longman.

Пипер, Клајн 2015: П. Пипер, И. Клајн, Нормативна граматика српског језика, Београд: Матица српска.

Пипер и др. (2005), П. Пипер и др., Синтакса савременог српског језика. Проста реченица, Београд: Институт за српски језик САНУ, Матица српска.

Хадлстон, Пулум 2002: R. Huddlestone, G. K. Pullum, The Cambridge Grammar of the English Language, Cambridge: Cambridge University Press.

Свартвик 1969: J. Svartvik, On Voice in the English Verb, The Hague/Paris: Mouton. 
Симеон 1969: Р. Симеон, Енциклопедијски рјечник лингвистичких термина, Загреб: Матица хрватска.

Симић 2001: Ж. Симић, Граматика српског језика, Београд: МХ Актуел.

Станојчић, Поповић 1995:, Ж. Станојчић, Љ. Поповић, Граматика српског језика за гимназије и средюе школе, Београд: Завод за уџбенике.

Стевановић 1951: М. Стевановић, Граматика српскохрватског језика, Београд: Знање.

Стевановић 1969: М. Стевановић, Савремени српскохрватски језик II, Синтакса: граматички системи и књижевнојезична норма, Београд: Научна књига.

Maja R. Kujundžić

\section{PASSIVE CONSTRUCTIONS IN THE TRANSLATION OF ANDRIĆ'S NOVEL "THE BRIDGE ON THE DRINA" INTO THE ENGLISH LANGUAGE}

The aim of this article is to compare the use of the passive construction in the English translation of Andric's novel 'The Bridge on the Drina" with its use in the original text of this novel. The main intention is to see whether passive constructions in the English translation appear or not in the same form in the orginal Serbian version, while at the same time trying to find out certain translating patterns that are possibly influenced by semantic, syntactic and stylistic characteristics that this construction have in the two contrasted languages. Therefore, in cases where such syntactic translation equivalence is not present, it will be necessary to compare the English passive construction with the Serbian active construction from which it originated in the process of translation and try to find out reasons for such choices, and whether, as such, they respresent certan translation patterns between the two languages. The same will be applied in cases where such syntactic equivalence is pres- 
ent i.e. where Serbian passive constructions were translated also by passive constructions in the English version of the text, where the main aim will be to see what types of passive were used in each respective langaage, whether those choices can be explained and supported by use of valid linguistic reasoning influenced by specific characteristics that passive has got in two contrasted languages, and wheteher, as in the previous case, those create certain translation patterns between the two languages.

Key words: passive construcion, original text, translation, types of passive, Serbian, English, contrastive analysis. 